\title{
Insulin-like growth factors (IGF) I and II in diabetic pregnancy: suppression of normal pregnancy-induced rise of IGF-I
}

\author{
B. Bhaumick ${ }^{1}$, A. D. Danilkewich ${ }^{2}$ and R. M. Bala ${ }^{1}$ \\ Departments of ${ }^{1}$ Medicine and ${ }^{2}$ Family Medicine, University of Saskatchewan, Saskatoon, Saskatchewan, Canada
}

\begin{abstract}
Summary. The concentrations of somatomedins/insulin-like growth factors were measured by a specific radioimmunoassay for insulin-like growth factor-I and a specific radioreceptor assay for insulin-like growth factor-II in sera of term normal and Type 1 (insulin-dependent) diabetic pregnant women and in various cord sera of their newborn infants. Serum insulin-like growth factor-I levels in normal (non-diabetic) maternal serum were higher than in non-pregnant women $(486 \pm 26$ versus $215 \pm 26 \mathrm{ng} / \mathrm{ml}$ ). The normal pregnancy-induced increment of insulin-like growth factor-I was markedly reduced in diabetic pregnancy. It was not different in patients with good or poor glycaemic control, as judged by normal or elevated blood levels of haemoglobin $A_{1 c}$ content. Insulin-like growth factor-I levels in cord serum of infants of diabetic women with good glycaemic control $(86 \pm 11 \mathrm{ng} / \mathrm{ml})$ and poor glycaemic control $(91 \pm 19 \mathrm{ng} / \mathrm{ml})$ were significantly higher $(p<0.01)$ than in infants of non-diabetic women $(43 \pm 42 \mathrm{ng} / \mathrm{ml})$. The fetal birth weight ratios were not significantly correlated with insulin-like growth factor-I levels in cord serum. Serum insulin-like growth factor-II levels in maternal and cord serum in diabetic and normal pregnancy were not different from each
\end{abstract}

other or from normal non-pregnant women. The increment in insulin-like growth factor-I levels in maternal serum in pregnancy may influence placental structure and function. Lack of this increment in maternal diabetes may have direct implication in placental abnormalities in diabetes and indirect implications on fetal development and metabolism. The increment in fetal serum insulin-like growth factor-I levels in infants of diabetic mothers might suggest a role for insulin-like growth factor-I in fetal macrosomia. This finding, along with the lack of correlation with maternal glycaemic control, might suggest that fetal hyperinsulinaemia has a greater role than insulinlike growth factor-I in the fetal macrosomia. Serum insulinlike growth factor-II levels do not appear to be influenced by pregnancy or diabetes. The similar levels of insulin-like growth factors-I or II in normal and diabetic non-pregnant women may present some evidence against a major role of both insulin-like growth factors in the chronic complications which may develop in persons with diabetes.

Key words: Insulin-like growth factors, diabetes, pregnancy, fetal growth.
Somatomedins (SM) or insulin-like growth factors (IGF) are growth hormone-dependent growth factors with insulin-like activity. IGF-I is a basic $\left(\mathrm{p}^{\mathrm{I}}>7.5\right) \mathrm{SM}$ [1]. Basic SM (B-SM,2) and SM-C [3] are considered to be functionally $[2,4]$ and structurally identical to IGF-I [5]. IGF-II [1] is a neutral ( $\mathrm{pI}<7.5) \mathrm{SM}$, and is the human counterpart of multiplication stimulating activity (MSA) in the rat [6]. Studies utilizing highly specific radioimmunoassays have shown that IGF increases during pregnancy [7-9], suggesting that IGF may have a role in the regulation of fetal growth and development. However, in the absence of evidence of placental transfer of the hormones, this action would need to be indirect by influencing placental metabolism or transport of maternal factors to the fetus [9]. Pregnant women with diabetes mellitus have been shown to have altered placental function [10]. The evaluation of IGF levels in dia- betic pregnancy may provide further understanding of the role of IGF in fetal growth. Several preliminary studies of IGF levels in pregnant and non-pregnant diabetic women have reported conflicting results [11-18]. We have therefore re-evaluated the levels of IGF in sera of a larger number of pregnant and non-pregnant diabetic patients and normal women and the infants at the time of delivery.

\section{Subjects and methods}

The subjects in this study included 32 normal non-diabetic and 34 diabetic pregnant women in their third trimester (30-40 weeks of gestation) and 14 normal and 25 diabetic non-pregnant women. The women were in an age group between 20 and 30 years. All the diabetic subjects were being treated with variable doses of insulin. The diabet- 
ic subjects were classified into two groups on the basis of glycaemic control as presumed to be reflected by blood haemoglobin $A_{1 c}$ $\left(\mathrm{HbA}_{1 \mathrm{c}}\right)$ concentrations. Those with $\mathrm{HbA}_{1 \mathrm{c}}$ levels within normal range $(5-7 \%)$ were designated as having good glycaemic control, while those with $\mathrm{HbA}_{1 \mathrm{c}}$ levels above the normal range were designated as having poor glycaemic control. None of the diabetic patients studied had acute metabolic or chronic complications of diabetes. All the apparently normal newborn babies of the diabetic mothers, irrespective of the glycaemic control, appeared normal other than for higher birth weight ratio (actual birth weight divided by 50 th percentile for sex corrected expected birth weight for gestational age [19]). Antecubital venous blood samples were obtained from the pregnant subjects on the day of delivery. Cord venous blood samples were obtained from the babies at the time of delivery. The blood samples were allowed to clot, centrifuged and the sera kept frozen at $-20 \mathrm{C}$ until assayed.

\section{Radioimmunoassay and radioreceptor assay}

IGF-I and II used in radioimmunoassay and radioreceptor assay were purified to homogeneity in our laboratory. IGF-I (B-SM) was purified as previously described [2] with the addition of reverse phase high pressure liquid chromatography (HPLC) in the final purification step. IGF-II was purified in a similar manner to IGF-I. The IGF-II containing fractions were separated from IGF-I by ion-exchange HPLC and further purified by isoelectric focusing followed by reverse phase HPLC. The purity of IGF-I and II was checked by a computerized spectral evaluation programme of the LKB HPLC system in addition to procedures previously described [2]. The estimated mol wt, receptor cross activity [20,21], sulfation factor activity and insulin-like activity $[4,22]$ of the purified IGF-II were similar to that reported for homogeneous IGF-II [1].

IGF-I was measured in acidified and lyophylized (AL) sera using a radioimmunoassay for B-SM as previously described [23]. IGF-II was measured in AL sera using a rat placental radioreceptor assay as described by Daughaday et al. [20].

The possible interference [24] of IGF binding proteins in serum on measurement of IGF in these studies was evaluated. Equal volumes of serum samples, pooled from subjects in the various study groups, were chromatographed on Sephadex G-75 $(0.7 \times 20 \mathrm{~cm}$ column $)$ with $1 \%(\mathrm{v} / \mathrm{v})$ formic acid. The fractions free of IGF binding protein, as assessed by failure to bind $\left[{ }^{125} \mathrm{I}\right] \mathrm{IGF}-\mathrm{I}$ or $\left[{ }^{125} \mathrm{I}\right] \mathrm{IGF}-\mathrm{II}$, were pooled, lyophylized, assayed by IGF-I radioimmunoassay and IGF-II radioreceptor assay and compared to IGF-I and II measured in sera which were only acidified and lyophilized.

\section{Statistical analysis}

Differences of serum IGF levels between groups were analyzed by one-way analysis of variance followed by Duncan's multiple range test.

\section{Results}

\section{Effects of pregnancy and diabetes on IGF-I levels}

The mean IGF-I levels in serum of normal (non-diabetic) and diabetic, non-pregnant and pregnant, subjects are shown in Figure 1. The mean serum IGF-I levels in non-pregnant diabetic patients were slightly higher than in non-pregnant normal subjects, but the differences were not significant.

Serum IGF-I levels in normal (non-diabetic) pregnant subjects were significantly higher $(p<0.01)$ than in

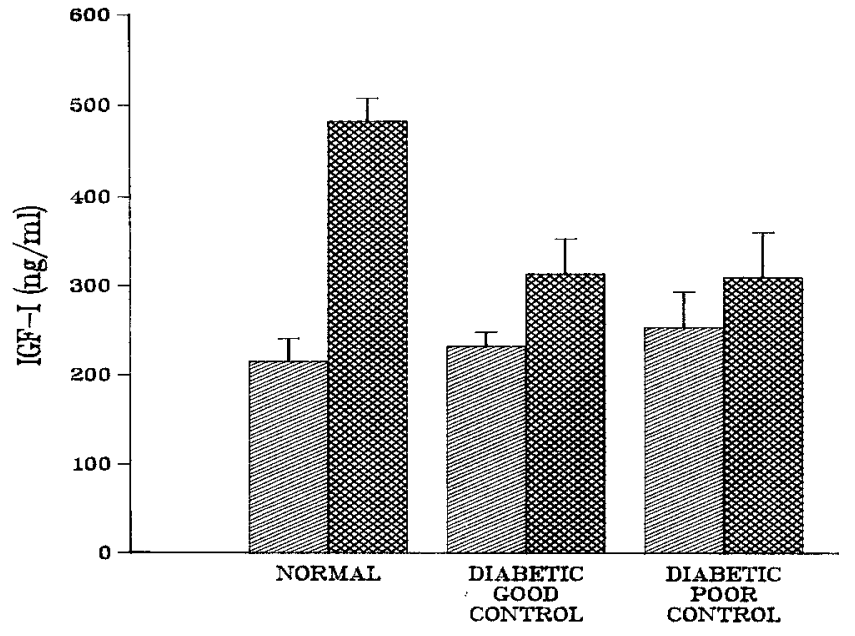

Fig. 1. Comparison of insulin-like growth factor-I (IGF-I) levels (mean \pm SEM) in serum of non-pregnant and diabetic women with good and poor glycaemic control. $n=14$ normal non-pregnant, 32 normal pregnant, 17 diabetic good control non-pregnant, 15 diabetic good control pregnant, 8 diabetic poor control non-pregnant, 9 diabetic poor control pregnant

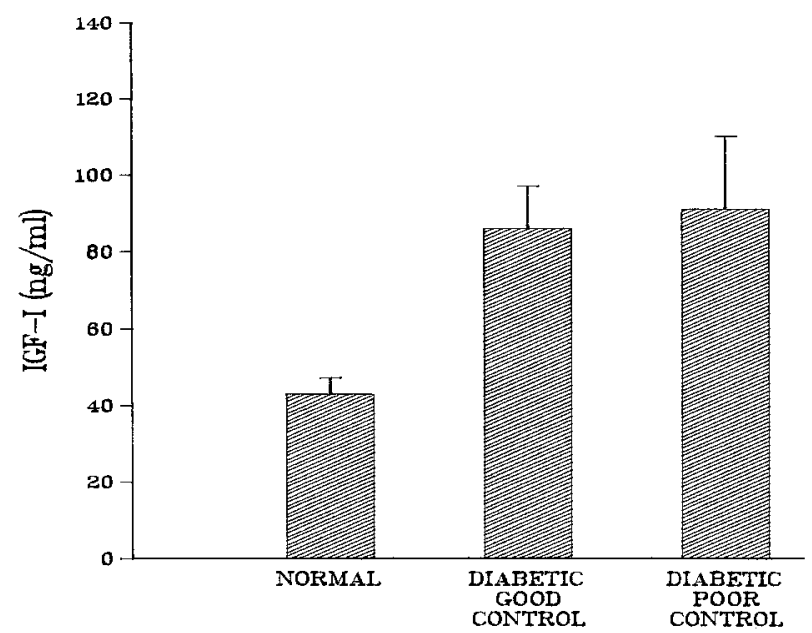

Fig. 2. Comparison of IGF-I levels (mean \pm SEM) in cord serum of newborn infants of normal $(n=27)$ and diabetic mothers with good $(n=15)$ and poor $(n=8)$ glycaemic control

normal non-pregnant subjects (approximately twofold). The mean serum IGF-I levels in pregnant diabetic patients were slightly higher compared to non-pregnant diabetic patients, but the differences were not significant. The mean serum IGF-I levels in pregnant diabetic patients were significantly lower $(p<0.05)$ than in pregnant non-diabetic (normal) women. There was no difference in the mean serum IGF-I levels in the diabetic subjects with good glycaemic control and poor glycaemic control within both the pregnant and non-pregnant groups.

As shown in Figure 2, IGF-I levels in cord venous serum of newborn infants of non-diabetic, good glycaemic control and poor glycaemic control mothers were significantly lower $(p<0.01)$ than those in normal 


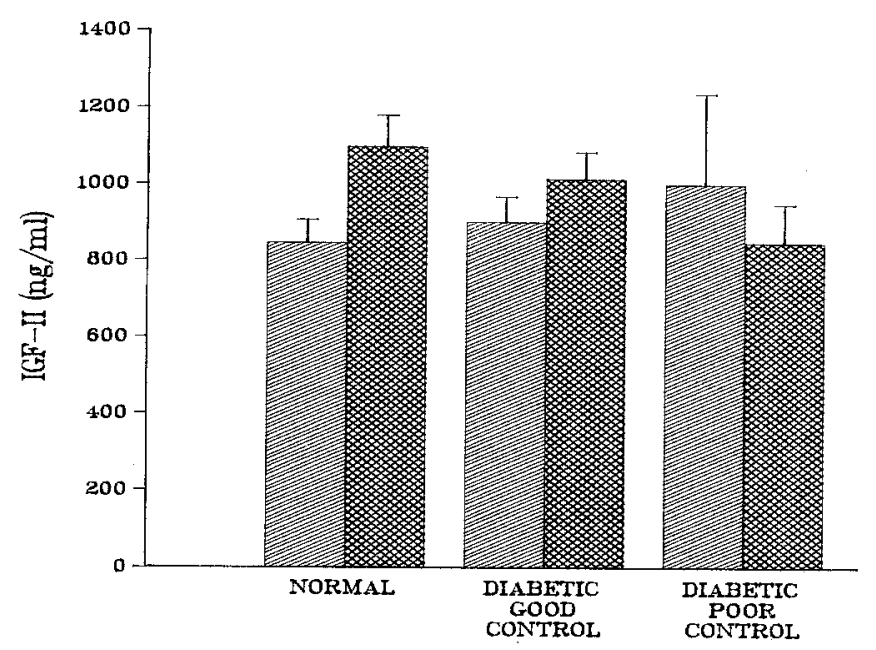

Fig. 3. Comparison of IGF-II levels (mean \pm SEM) in maternal serum of non-pregnant and pregnant diabetic women with good and poor glycaemic control. $n=9$ normal non-pregnant, 32 normal pregnant, 14 diabetic good control nonpregnant, 15 diabetic good control pregnant, 8 diabetic poor control non-pregnant, 9 diabetic poor control pregnant

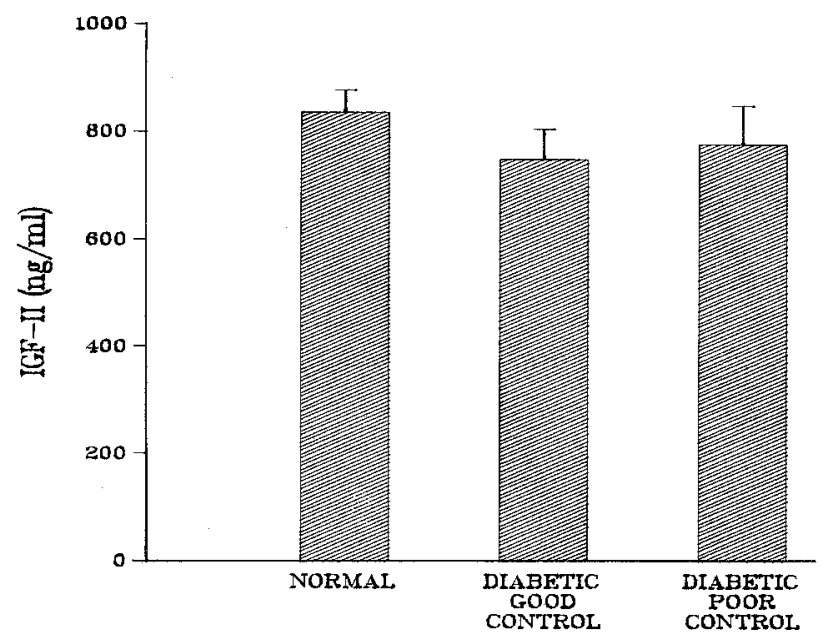

Fig.4. IGF-II levels (mean \pm SEM) in cord serum of infants of normal $(n=17)$ (non-diabetic) and diabetic mothers with good $(n=15)$ and poor $(n=9)$ glycaemic control

adults (Fig. 1). IGF-I levels in good glycaemic control and poor glycaemic control cord serum were not different, but both groups revealed significantly higher $(p<$ $0.01)$ levels than in normal cord serum. Cord serum IGF-I levels were not significantly correlated with infant birth weight ratios.

\section{Effects of pregnancy and diabetes on IGF-II levels}

Figure 3 shows the mean IGF-II levels in normal and diabetic non-pregnant and pregnant subjects. The mean levels of serum IGF-II appeared higher in the non-pregnant diabetic patients (diabetic poor control $>$ diabetic good control) than in non-pregnant normal (non-diabetic) subjects, but the differences were not significant. The mean serum IGF-II levels appeared lower in the pregnant diabetic patients (diabetic poor control $<$ diabetic good control) than in pregnant non-diabetic subjects, but the differences were not significant. The serum IGF-II levels were not significantly different between the pregnant and non-pregnant diabetic subjects with poor and good glycaemic control.

The mean serum levels of IGF-II in venous cord serum (Fig. 4) and corresponding maternal serum levels (Fig.3) were not significantly different from infants of non-diabetic (normal) mothers. The mean serum IGFII levels in venous cord serum (Fig.4) in infants from diabetic mothers, with good and poor glycaemic control, were lower than in those from non-diabetic mothers, but the differences were not significant.

\section{Effects of serum binding proteins on measurement of IGF}

To evaluate the possible interference in the radioimmunoassay and radioreceptor assay by serum IGF binding proteins, we measured IGF-I and II levels on pooled sera from different subjects in the same groups before and after acidic gel filtration. The results are shown in Tables 1-4. The mean levels of IGF-I measured were similar, being within the range of intra-assay variation, before and after acidic gel filtration. The mean IGF-II levels were lower in all of corresponding group sera after acidic gel filtration. However, the levels observed in different groups, similar to non-filtered serum, did not reveal significant differences among the groups.

\section{Discussion}

The radioimmunoassay used for IGF-I measurements in these studies has high specificity with minimal crossreactivity with IGF-II [23]. Our previous studies [23] and

Table 1. Insulin-like growth factor-I (IGF-I) levels in maternal serum of pregnant and non-pregnant normal and diabetic women with good and poor glycaemic control measured by radioimmunoassay before and after acidic gel filtration

\begin{tabular}{|c|c|c|c|c|}
\hline & \multicolumn{4}{|c|}{ IGF-I (ng/ml) } \\
\hline & \multicolumn{2}{|c|}{ Non-pregnant } & \multicolumn{2}{|l|}{ Pregnant } \\
\hline & Before & After & Before & After \\
\hline $\begin{array}{l}\text { Normal } \\
(n=5)\end{array}$ & $223 \pm 23$ & $218 \pm 32$ & $407 \pm 23$ & $425 \pm 25$ \\
\hline $\begin{array}{l}\text { Diabetic good } \\
\text { control } \\
(n=2, \text { non-pregnant }) \\
(n=5, \text { pregnant })\end{array}$ & $194 \pm 3$ & $213 \pm 12$ & $249 \pm 28$ & $243 \pm 25$ \\
\hline $\begin{array}{l}\text { Diabetic poor } \\
\text { control } \\
(n=4)\end{array}$ & $200 \pm 10$ & $205 \pm 13$ & $267 \pm 32$ & $240 \pm 15$ \\
\hline
\end{tabular}

Equal volumes of serum from different subjects in each study group were pooled and IGF-I was measured by radioimmunoassay in each pooled serum before and after acidic gel filtration. The average ( \pm $1 / 2$ range, based on duplicate assays) IGF-I concentration in the pooled sera, before and after gel filtration, are shown 
Table 2. Insulin-like growth factor-I (IGF-I) levels in cord serum of infants of normal and diabetic mothers measured by radioimmunoassay before and after gel filtration of the sera

\begin{tabular}{lcc}
\hline & \multicolumn{2}{l}{ IGF-I $(\mathrm{ng} / \mathrm{ml})$} \\
\cline { 2 - 3 } & Before & After \\
\hline $\begin{array}{l}\text { Normal } \\
(n=5)\end{array}$ & $60 \pm 7$ & $57 \pm 4$ \\
$\begin{array}{l}\text { Diabetic good control } \\
(n=5)\end{array}$ & $85 \pm 16$ & $93 \pm 12$ \\
$\begin{array}{l}\text { Diabetic poor control } \\
(n=5)\end{array}$ & $112+12$ & $102+3$ \\
\hline
\end{tabular}

The sera were pooled and the results expressed similar to those in Table 1

Table 3. Insulin-like growth factor-II (IGF-II) levels in maternal serum of pregnant and non-pregnant normal and diabetic women with good and poor glycaemic control measured by radioreceptor assay before and after acidic gel filtration of sera

\begin{tabular}{|c|c|c|c|c|}
\hline & \multicolumn{4}{|c|}{ IGF-II (ng/ml) } \\
\hline & \multicolumn{2}{|c|}{ Non-pregnant } & \multicolumn{2}{|l|}{ Pregnant } \\
\hline & Before & After & Before & After \\
\hline $\begin{array}{l}\text { Normal } \\
(n=5)\end{array}$ & $697 \pm 36$ & $673 \pm 29$ & $857 \pm 20$ & $580 \pm 19$ \\
\hline $\begin{array}{l}\text { Diabetic good } \\
\text { control } \\
(n=2, \text { non-pregnant }) \\
(n=5, \text { pregnant })\end{array}$ & $768 \pm 25$ & $580 \pm 10$ & $800 \pm 23$ & $637 \pm 20$ \\
\hline $\begin{array}{l}\text { Diabetic poor } \\
\text { control } \\
(n=4)\end{array}$ & $860 \pm 27$ & $784 \pm 17$ & $870 \pm 33$ & $751 \pm 47$ \\
\hline
\end{tabular}

The sera were pooled and the results expressed similar to those noted for IGF-I in Tables 1-2

Table 4. Insulin-like growth factor-II (IGF-II) levels in cord venous serum of infants of normal and diabetic mothers by radioreceptor assay before and after acidic gel filtration of sera

\begin{tabular}{lll}
\hline & \multicolumn{2}{l}{ IGF-II (ng/ml) } \\
\cline { 2 - 3 } & Before & After \\
\hline $\begin{array}{l}\text { Normal } \\
(n=5)\end{array}$ & $865 \pm 25$ & $605 \pm 21$ \\
$\begin{array}{l}\text { Diabetic good control } \\
(n=5)\end{array}$ & $700 \pm 20$ & $624 \pm 15$ \\
$\begin{array}{l}\text { Diabetic poor control } \\
(n=5)\end{array}$ & $828 \pm 40$ & $635 \pm 25$ \\
\hline
\end{tabular}

The sera were pooled and the results expressed similar to those noted in Table 3

the results reported here indicate that the pre-assay procedures of acidification and lyophilization of serum minimize the potential adverse effects of binding protein on the measurement of IGF-I in serum.

Our results showing increased levels of IGF-I in serum in pregnancy are in agreement with those previously reported by us [9] and others [7, 8]. The mechanism for the marked increase of IGF-I levels in pregnancy is not understood. It is possible that total IGF-I levels in serum increase due to an increase in amount or binding capacity of serum IGF binding proteins, resulting in an increased total amount of bound IGF which is measured by the radioimmunoassay. Alternatively, it is possible that pregnancy-associated increase in hormones, such as hPL and prolactin, increase IGF-I production [7]. The physiologic role of IGF-I in the adult is not fully defined; however, it is assumed to mediate at least some of the action of $\mathrm{GH}$ on tissue growth and metabolism. It would be speculative to postulate the role of increased levels of IGF-I on the pregnant mother, particularly if the total IGF levels are elevated without increase in the free or unbound, biologically active, form of IGF-I in the circulation. It is possible that the high levels of IGF-I in the maternal circulation stimulate placental growth and modulate its metabolic functions, particularly in its production and secretion of various hormones into the maternal and fetal circulation.

We did not find significant differences in serum total IGF concentration in non-pregnant diabetic patients and normal female subjects. This may present some evidence against a potential role of IGF in the chronic complication which may occur in patients with diabetes. The effects of diabetes on serum levels of IGF-I in pregnancy are of interest but not readily explained. Diabetes suppressed the normal increment in serum IGF-I levels in pregnancy, and this appeared to be independent of glycaemic control. This would suggest that factors in diabetes apart from the hyperglycaemic and other metabolic derangements consequent to relative insulin deficiency are responsible for suppression of the normal pregnancy-induced increase in total serum IGFI. Susa et al. [11] reported similar serum levels of IGF-I in normal and diabetic pregnant subjects, but they also reported serum levels of IGF-I in normal pregnancy that were similar to that previously reported by them [7] and others $[8,9,25]$ in non-pregnant normal subjects. The differences in these results are not readily explained. Since a specific role for IGF-I in normal pregnancy has not been defined, it is difficult to speculate as to the potential pathophysiological significance of the impaired increment in maternal serum IGF-I levels in diabetic subjects during pregnancy.

Our finding of low levels of IGF-I in newborns compared to adults are in agreement with previous reports by us [9] and others [26]. The findings of increased levels of IGF-I in cord serum from infants of diabetic mothers is of interest. In view of the lower levels of IGF-I in maternal serum of diabetic patients compared to normal subjects, this would again argue against significant transplacental transfer of IGF-I from the mother to the fetus. Since we did not measure hPL, GH, or prolactin in cord serum, we cannot speculate regarding their potential role in increasing the levels of IGF-I in cord serum from infants of diabetic mothers. It is possible that high serum glucose levels in the mother resulting in fetal hyperglycaemic hyperinsulinaemia with increased glucose utilization augment IGF-I production by the fetal liver and other tissues in response to other 
regulators. It is possible that the increased fetal levels of IGF-I have a role in fetal macrosomia. However, the lack of correlation between cord serum IGF-I levels and birth weight ratios would further support the previous suggestions [11] that insulin has a more important role than IGF-I in the etiology of fetal macrosomia in diabetic pregnancy.

Our findings of no significant differences in serum levels of IGF-II in pregnant and non-pregnant diabetic and non-diabetic women are in general agreement with previous reports [13-15] and other studies using a Cpeptide specific radioimmunoassay [7]. This may suggest that IGF-II has no significant influence in metabolic alterations in the mother during pregnancy and does not have a major direct role in potential pathological consequences in diabetic persons.

Our findings of similar IGF-II concentrations in cord serum from infants of normal and diabetic women to that in serum from pregnant and non-pregnant women is in agreement with previous reports measuring IGF-II by radioreceptor assay [27, 28] but differs from other reports showing lower IGF-II levels, measured by radioimmunoassay [11,25], in cord serum of the infants than in normal maternal serum. It is possible that the radioimmunoassay more accurately measures IGF-II levels, since the radioreceptor assay does appear to be influenced by IGF binding proteins. We are therefore reluctant to suggest that our studies, based on radioreceptor assay measurements of IGF-II, argue against a potential significant role of IGF-II in the etiology of fetal macrosomia in diabetes with poor glycaemic control during pregnancy. The increase of IGF-I in the serum of infants of diabetic mothers, along with the impaired increment in serum IGF-I levels during pregnancy in diabetic women, may suggest that IGF-I production is significantly dependent upon nutrient metabolism, in particular glucose, by the liver. Conversely the lack of similar observations related to serum levels of IGF-II may suggest that production of IGF-II is not similarly modulated by glucose metabolism and increases of various hormones in pregnancy.

Acknowledgements. We would like to acknowledge the secretarial services of Ms M.Paynter and the technical assistance of Mr. W.C. Hodgson. This work was supported by a grant from the Canadian Diabetes Association. Presented in part at the 45th Annual Meeting of the American Diabetes Association, 1985.

\section{References}

1. RinderknechtE, Humbel RE (1976) Polypeptides with nonsuppressible insulin-like and cell-growth promoting activities in human serum: isolation chemical characterization and some biological properties of forms I and II. Proc Natl Acad Sci USA 73: 2365-2369

2. Bala RM, Bhaumick B (1979) Purification of a basic somatomedin from human plasma cohn fraction IV-I, with physicochemical and radioimmunoassay similarity to somatomedin- $\mathrm{C}$ and insulin-like growth factor. Can J Biochem Cell Biol 57: 1289-1298
3. Svoboda ME, Van WykJJ, Knapper DG, Fellow RE, Grissom FE, Schlneter RJ (1980) Purification of somatomedin-C from human plasma: chemical and biological properties, partial sequence analysis and relationship to other somatomedins. Biochemistry 19: 790-797

4. Bhaumick B, Goren HJ, Bala RM (1981) Further characterization of human basic-somatomedin; comparison with insulin-like growth factors I and II. Horm Metab Res 13: 515-518

5. Klepper DG, Svoboda ME, Van Wyk JJ (1983) Sequence analysis of somatomedin-C; confirmation of identity with insulin-like growth factor-I. Endocrinology 112: 2215-2217

6. Moses AC, Nissley SP, ShortPH, RechlerMM, Podskalny JM (1980) Purification and characterization of multiplication stimulating activity, insulin-like growth factors from rat liver conditioned medium. Eur J Biochem 103: 387-400

7. Wilson WM, Bennett A, Adamson GD, Nagashima RJ, Liu F, DeNatale ML, HintzRL, Rosenfeld RG (1982) Somatomedins in pregnancy: a cross-sectional study of insulin-like growth factors I and II and somatomedin content, peptide content in normal human pregnancy. J Clin Endocrinol Metab 55: 858-561

8. Furlanetto RW, Underwood LE, Van WykJJ, D'Ercole AJ (1977) Estimation of somatomedin-C levels in normals and patients with pituitary disease by radioimmunoassay. J Clin Invest 60: 648-657

9. Bala RM, Lopatke J, Leung A, McArthur RG (1981) Serum immunoreactive somatomedin levels in normal adults, pregnant women at term, children at various ages, and children with constitutionally delayed growth. J Clin Endocrinol Metab 52: 508-512

10. WhitsettJA, Brownscheidle CM (1979) Aspects of placental structure and function in maternal diabetes. In: Merkatz IR, Adama PAJ (eds) The diabetic pregnancy: a perinatal perspective. Grune and Stratton, New York, p 123

11. Susa JB, Widness JA, Hintz R, Lin F, Seghal P, Schwartz R (1984) Somatomedins and insulin in diabetic pregnancies: effects on fetal macrosomia in the human and rhesus monkey. J Clin Endocrinol Metab 58: 1099-1105

12. Rieu M, Binoux M (1985) Serum level of insulin-like growth factor (IGF) und IGF binding protein in insulin dependent diabetes during an episode of severe metabolic decompensation and the recovery phase. J Clin Endocrinol Metab 60: 781-785

13. Merimee TJ, Zapf J, Froesch ER (1983) Insulin-like growth factors, studies in diabetes with and without retinopathy. New Engl J Med 309: 527-530

14. Lamberton PR, Goodman AD, KassoffA, Rubin CL, Treble DH, Saba TM, Merimee TJ, Dodds WJ (1984) Von Willebrand factor (VIII R: Ag), fibronectin, and insulin-like growth factors I and II in diabetic retinopathy and nephropathy. Diabetes 33:125-129

15. Merimee TJ, Gardner DF, Zapf J, Froesch ER (1984) Effect of glycemic control on serum insulin-like growth factors in diabetes mellitus. Diabetes 33: 790 -793

16. Blethen SL, Sargeant DT, Whitlow MG, Santiago JV (1981) Effect of pubertal stage and recent blood glucose control on plasma somatomedin $\mathrm{C}$ in children with insulin-dependent diabetes mellitus. Diabetes 30: 868-872

17. Tamborlane WV, Raymond LH, Bergman M, Genel M, Felig P, Sherwin RS (1981) Insulin-infusion pump treatment of diabetes, influence of improved metabolic control on plasma somatomedin levels. New Engl J Med 305: 303-307

18. Horner JM, KempSF, Hintz RL (1981) Growth hormone and somatomedin in insulin-dependent diabetes mellitus. I Clin Endocrinol Metab 53: 1148-1153

19. Brenner WE, Edelman DA, Hendricks CH (1976) Standards of fetal growth for the United States of America. Am J Obstet Gynecol 126: 555

20. Daughaday WH, Maritz IK, Trivedi B (1981) A preferential binding site for insulin-like growth factor II in human and rat placental membranes. J Clin Endocrinol Metab 53: 282-288

21. Bhaumick B, Bala RM (1985) Ontogeny and characterization of basic somatomedin receptors in rat placenta. Endocrinology 116: $492-497$

22. Zapf J, Schoenle U, Froesch ER (1978) Insulin-like growth factors I and II: some biological actions receptor binding characteris- 
tics of two purified constituents of non-suppressible insulin-like activity from human serum. Eur J Biochem 87: 285-296

23. Bala RM, Bhaumick B (1979) Radioimmunoassay of a basic somatomedin: comparison of various assay techniques and somatomedin levels in various sera. J Clin Endocrinol Metab 49: 770-777

24. Daughaday WH, Parker KA, BorowskyS, Trivedi B, KapadiaM (1982) Measurement of somatomedin-related peptides in fetal, neonatal and maternal rat serum by insulin-like growth factor (IGF) I radioimmunoassay. IGF-II radioreceptor assay (RRA) and multiplication stimulating RRA after acid-ethanol extraction. Endocrinology 110: 575-581

25. Zapf J, Walter H, Froesch ER (1981) Radioimmunological determination of insulin-like growth factors I and II in normal subjects and in patients with growth disorders and extrapancreatic tumor hypoglycemia. J Clin Invest 68: 1321-1330

26. Schimpff RM, Bozzola M, Zapf J (1985) Serum thymidine activity and insulin-like growth factors in the neonatal period. Acta Endocrinol 110: 140-144
27. Bennet A, Wilson DFM, Liu F, Nagashima R, Rosenfeld RG, Hintz RL (1983) Levels of insulin-like growth factors I and II in human cord blood. J Clin Endocrinol Metab 57: 609-611

28. Gluckman PD, Johnson-Barret JJ, Butler JH, Edgar BW, Gun TR

(1983) Studies on insulin-like growth factor I and II by specific radioligand assays in umbilical cord blood. Clin Endocrinol (Oxf) 19: 405-413

Received: 16 June 1986

and in revised form: 1 October 1986

Dr. B. Bhaumick, Department of Medicine, CMR Building, University of Saskatchewan, Saskatoon, Saskatchewan S7N OWO Canada 